\title{
STONES, BONES, AND HILLFORT: RADIOCARBON DATING OF ĶIVUTKALNS BRONZE-WORKING CENTER
}

\author{
M Oinonen ${ }^{1,2} \cdot$ A Vasks $^{3} \cdot$ G Zarina $^{3} \cdot$ M Lavento $^{4}$ \\ ABSTRACT. The Bronze Age site of Ķivutkalns with its massive amount of archaeological artifacts and human remains is \\ considered the largest bronze-working center in Latvia. The site is a unique combination of cemetery and hillfort believed to \\ be built on top of each other. This work presents new radiocarbon dates on human and animal bone collagen that somewhat \\ challenge this interpretation. Based on analyses using a Bayesian modeling framework, the present data suggest overlapping \\ calendar year distributions for the contexts within the 1st millennium BC. The carbon and nitrogen isotopic ratios indicate \\ mainly terrestrial dietary habits of studied individuals and nuclear family remains buried in one of the graves. The older char- \\ coal data may be subject to the old-wood effect and the results are partly limited by the limited amount of data and the ${ }^{14} \mathrm{C}$ cal- \\ ibration curve plateau of the 1st millennium BC. Therefore, the ultimate conclusions on contemporaneity of the cemetery and \\ hillfort need to wait for further analyses on the massive amounts of bone material.
}

\section{INTRODUCTION}

Neolithic traditions of amber and flint working in Latvian territory started to change gradually after the introduction of bronze. Within that development, the hillfort and cemetery of Kivutkalns holds a special place among archaeological sites of the Bronze and earliest Iron Age in Latvia, and indeed within the whole of the east Baltic. Compared with other sites, it has provided the richest evidence concerning the structures and economic basis of a fortified settlement, as well as the burial practices. Thus, the site is considered the largest Late Bronze Age bronze-working center in Latvia. One third of the archaeological artifacts found at Ķivutkalns hillfort in the lower Western Dvina River are related to bronze working (Vasks 2010). The Ķivutkalns was a double monument: according to archaeological evidence, a fortified residential site had been established directly on top of what had originally been a burial site. This in itself is an unusual, even a unique case.

The cultural layer, 1.6-3 m thick, which covered the cemetery like a kind of shell, protected it from the harmful effects of the atmosphere and precipitation, and meant that most of the skeletons were well preserved. It is also important that all the burials in the cemetery were preserved (231 inhumations and 20 cremations (Denisova et al. 1985:10). Accordingly, the cemetery can be regarded as a precise archaeological reflection of a particular Bronze Age society, providing broad opportunities for research on physical anthropology and paleodemography, and for the interpretation of the social system of the particular society, as well as for other approaches to the characterization of human society.

Kivutkalns (Figure 1) was located on the island of Dole, on the lower course of the Western Dvina River (in Latvia, known as the Daugava River), on a sandy spit of land formed by the former shore of the Western Dvina and the bed of a former river channel that is now hard to distinguish. The hillfort plateau, an area of even ground about $40 \mathrm{~m}$ in diameter falling away gently towards the south, was delimited on the north side, facing the river, by a steep slope $\sim 10 \mathrm{~m}$ high. The western and southern slopes were less steep, 5-6 m and $3 \mathrm{~m}$ high, respectively. On the eastern side, the hill rose only $\sim 1.5 \mathrm{~m}$ above the adjacent field.

\footnotetext{
${ }^{1}$ Finnish Museum of Natural History - LUOMUS, University of Helsinki, Finland.

${ }^{2}$ Corresponding author. Email: markku.j.oinonen@helsinki.fi.

${ }^{3}$ Institute of Latvian History, University of Latvia, Latvia.

${ }^{4}$ Department of Philosophy, History, Culture and Art Studies, University of Helsinki, Finland.
}

(c) 2013 by the Arizona Board of Regents on behalf of the University of Arizona

Proceedings of the 21st International Radiocarbon Conference edited by A J T Jull \& C Hatté

RADIOCARBON, Vol 55, Nr 2-3, 2013, p 1252-1264 


\section{Oinonen et al.}

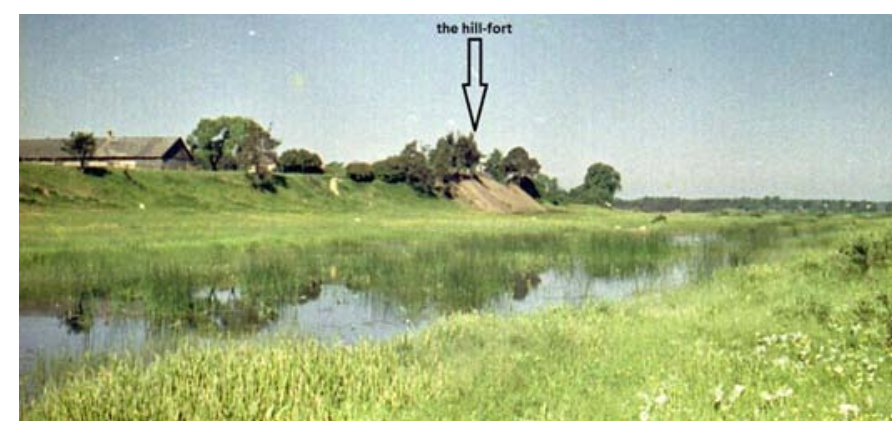

Figure 1 Site of Ķivutkalns hillfort in the island of Dole at the Daugava River

The Ķivutkalns site was totally excavated under the direction of Jānis Graudonis in 1966 and 1967 in connection with the building of the Riga Hydroelectric Plant. Even though detailed studies have been published about the hillfort, and in particular about the cemetery (Graudonis 1989; Denisova et al. 1985), the chronological relationship between these 2 sites has not been entirely clear. Based on ${ }^{14} \mathrm{C}$ dating and typological dating of the find material, the hillfort was placed in the 1st millennium BC (Graudonis 1989). There were no ${ }^{14} \mathrm{C}$ dates for the cemetery, and the few artifacts from the burials could only be dated within a very broad interval. Thus, the date of establishment of the cemetery and its duration of use remained unclear, as discussed below, although the archaeological interpretation was to consider that the cemetery predated the hillfort.

In order to obtain more precise evidence regarding the chronology of the cemetery and the hillfort, we have performed 2 sets of analyses. In 2008, human bone samples were selected from 5 burials. In 2010, an additional 3 samples were taken from animal bone objects found in the hillfort from different depths in the cultural layer. All the samples were then analyzed by the Laboratory of Chronology (former Dating Laboratory) at the Finnish Museum of Natural History - LUOMUS, University of Helsinki, with ${ }^{14} \mathrm{C}$ and stable isotopic methods. In this paper, we discuss the site with respect of the old and recent ${ }^{14} \mathrm{C}$ studies of the context, supported by $\delta^{13} \mathrm{C}$ and $\delta^{15} \mathrm{~N}$ values of animal and human bone collagen.

\section{BACKGROUND}

The general changes in northern Europe at the turn of the 1st millennium BC are remarkable (Lang 2007b:241). Particularly, the building of hillforts began at that time. Considering the whole Baltic region, the first half of the 1st millennium BC seems to be the most active time for building of hillforts. The first hillfort building period in Scandinavia was also soon after the turn of the 1st millennium BC (Stenberger 1979:252). The beginning of building took place almost synchronously in the large area of northern and eastern Europe. As a result, the culture changed quickly during a relatively small timescale.

Concerning the Ķivutkalns site, a comprehensive typological analysis and chronological evaluation for the hillfort was given by Graudonis (1989:20-46). Altogether, 2700 artifacts have been recovered; however, only certain bronze objects were suitable for typological dating the time of occupation of the hillfort. For the artifacts made of other materials (stone, bone, antler, etc.), only a very broad time interval could be given — to the nearest quarter of a millennium or even less precisely.

Of the bronze objects, 3 hoards were important. The first consisted of 2 neck rings and the remains of a tutulus and a diadem or bracelet. These were found in a hearth at a depth of 160-168 cm, at the 


\section{Stones, Bones, and Hillfort: ${ }^{14} \mathrm{C}$ Dating of Kivutkalns}

very base of the cultural layer, and so could indicate the time when habitation on the hillfort began. Graudonis (1989:41) dated the hoard to the 8th/7th century BC, with the possibility that it could be from the 7th century BC. The second hoard, consisting of a bronze socketed axe, a bracelet of circular section, and a flat spiral dress pin, was found at a depth of $80-90 \mathrm{~cm}$. This hoard was dated to the very end of the Bronze Age: the 7th-6th century BC (Graudonis 1989:41-2). The third hoard on Ķivutkalns had been found in the course of ploughing on the hillfort plateau in 1942. It consisted of 2 bronze bracelets, only one of which had ended up in the museum. This closed solid bronze bracelet with a pronounced lateral projection was dated by L Vankina to Period V of the Bronze Age, i.e. 950-750 BC (Vankina 1960:159).

According to later studies, Period V of the Bronze Age seems to date slightly later to 850-760 BC (Vandkilde 1996), agreeing with Graudonis (1989:42). However, considering that both bracelets were found in the course of ploughing on the hillfort plateau, i.e. at the top of the cultural layer, such an early date seems doubtful. If the bracelet dates from the time of the establishment of the hillfort, in stratigraphic terms it should have originated from deeper strata of the cultural layer, rather than the surface. Of course, it should be borne in mind that the cultural layer could have been disturbed in the course of rebuilding work, bringing up artifacts from deeper layers to the upper layers. However, in this case 2 bracelets were found together, indicating a hoard (Graudonis 1989:11), and these 2 items could probably not have been brought up to the top stratum of the cultural layer together. There are no direct analogies for the bracelet. A similar type of bracelet, but with a narrower loop and a slight lateral projection, has been found in Lithuania, dated to the end of Period V or the beginning of Period VI (Grigalavičiene and Merkevičius 1980:57). Given that this bracelet comes from the upper part of the cultural layer, it may be dated to Period VI, i.e. the 7th-6th century BC.

The terminal from a neck ring with upturned trumpet terminals was dated by Graudonis (1989:43) to the second quarter of the 1 st millennium BC, i.e. $750-500$ BC. In this, he was evidently guided by stratigraphic considerations: the find was recovered at $135 \mathrm{~cm}$ depth. However, based on some analogies, the find should be dated later. For example, a trumpet terminal from a neck ring found at the cemetery of Laidzes Lazdini is dated to the 2nd-1st century BC (Vasks 2003:145). Neck rings with upturned trumpet terminals from Lithuania are dated similarly (Grigalavičiene and Merkevičius 1980:52). Evidently, the Ķivutkalns find may be of a similar date. A double button is dated to the 3rd-1st century BC (Graudonis 1989:6, Figure XXXII). Headband ornaments of this kind are known from the Ananino culture and in the earliest Iron Age of Estonia (Vasks 1994:43; Lang 2007a:185). Three iron knives, 1 whole and 2 others fragmentary, relate to the very end of habitation at Kivutkalns hillfort (Graudonis 1989:1-3, Figure 25). They are difficult to date, but most probably belong to the period from the 2nd-1st century BC up to the 1st century AD. Thus, based on analogies in eastern and northern Europe, the oldest of the typologically datable metal objects are from the 7th-6th century BC, and the youngest are from the 3rd-2nd century BC up to the 1st century $\mathrm{AD}$. Based on the dates of these artifacts, Kivutkalns hillfort may be seen as having existed from the 7th-6th century BC up to the 1st century AD.

${ }^{14} \mathrm{C}$ datings on charcoal have been previously used for natural scientific dating of the hillfort (Graudonis 1989). A total of 6 charcoal samples and 1 sample of partly decomposed wood from the cultural layer of the hillfort were dated. Dating was carried out by what was then the laboratory of the Institute of Zoology and Botany of the Academy of Sciences of the Estonian SSR in Tartu (lab code: TA), the laboratory of the Leningrad Branch of the Institute of Archaeology of the USSR Academy of Sciences (lab code: LE), and the Laboratory of Geology and Geophysics of the USSR Ministry of Gas Industry (lab code: Ri) (Table 1). The resulting dates range from 2750 to $1920 \mathrm{BP}$. 


\section{Oinonen et al.}

Since there were no ${ }^{14} \mathrm{C}$ dates for the cemetery, dating of the cemetery was based on the finds recovered from the graves and on the position of the cemetery in relation to the hillfort. Grave goods, 66 in total, were found in 56 out of 231 inhumations. In some graves, domestic animal bones were present-evidence of the provision of food for the deceased. Of the artifacts, 51 were bone dress pins with a flat head, having 1 or 2 perforations for a string. The remaining finds were amber and animal tooth pendants, bone awls, a small pottery bowl, a core from drilling a stone axe shaft-hole and a bronze spiral (Denisova et al. 1985: Figures 33, 34). The ornaments from the cemetery are typologically similar to those found in the cultural layer of the hillfort. Unfortunately, the bone needles, like the other artifacts from the burials, can only be typologically dated to the nearest century or two. Overall, the finds date to the Late Bronze Age and the beginning of the pre-Roman Iron Age, i.e. from the end of the 2nd millennium BC up to the final quarter of the 1st millennium BC. However, the period of use of the cemetery is indicated also by its position (beneath the hillfort). There are several characteristics indicating that the hillfort was built directly on top of the cemetery and burial did not continue after construction of the fortifications and residential structures of the hillfort. Firstly, the burials were arranged very close together, and such an arrangement would not have been possible had burial been undertaken within the densely built-up hillfort. Secondly, after removal of the charcoal-rich cultural layer of the hillfort, with a thickness of $1.6-3 \mathrm{~m}$, the gray upper horizon of a paleosoil was uncovered throughout the area, revealing the elongated outlines of the graves. The grave fills consisted of yellow sand, mixed with inclusions from the gray soil layer. Had burial taken place during the time of habitation of the hillfort, remains from the cultural layer would inevitably have found their way into the grave fills, but these were absent. Thirdly, in several cases where the burials were located in the area of the hillfort defences, they were cut by the post-holes of the fortification system, indicating that the graves predate the defenses.

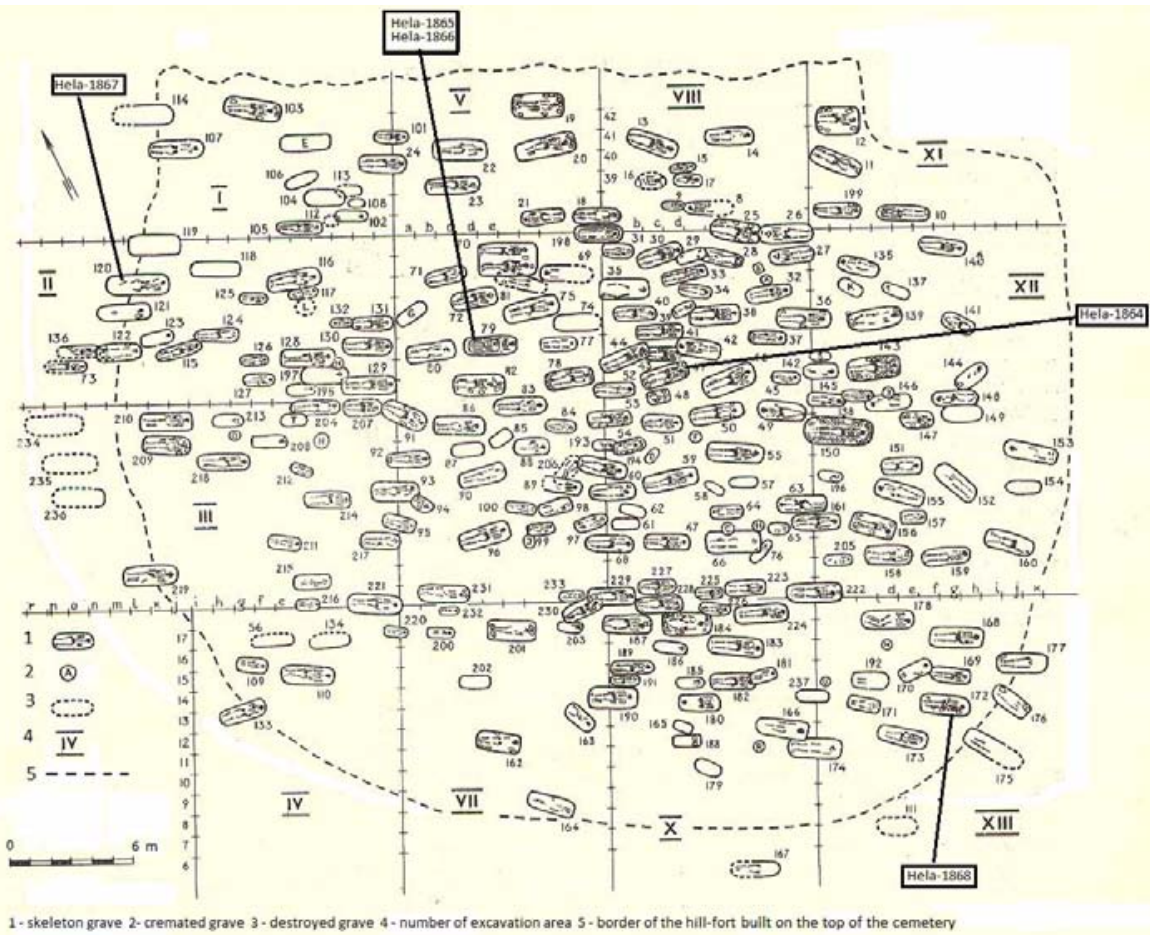

Figure 2 Plan of the Ķivutkalns cemetery beneath the hillfort 


\section{Stones, Bones, and Hillfort: ${ }^{14} \mathrm{C}$ Dating of Kivutkalns}

This all indicates that the cemetery is older than the hillfort, i.e. construction of the hillfort could have commenced only after the cemetery had gone out of use. In view of these considerations, the cemetery must be earlier than the 7th century BC, but when compared against the artifact datings, the case is not entirely clear.

\section{METHODS}

Animal bone samples from the hillfort (3 total) were taken at various depths in the cultural layer. Sample 1, a bone splinter with traces of working, was recovered in Area 10 at $0.75 \mathrm{~m}$ depth. Sample 2, a bone awl, was found in Area 12 at a depth of $1.53 \mathrm{~m}$. Sample 3, a bone awl, was found in Area 10 at a depth of $1.90 \mathrm{~m}$.

Human bone samples ( 5 altogether) from the cemetery were chosen so as to include both the central part of the cemetery and its periphery. In the central part, samples were taken from Burial 47 (Sample 1, male aged 35-40), Burial 79a (Sample 2, child, aged 2), and Burial 79b (Sample 3, male aged 35-45). Sample 4 was taken from Burial 120 (male aged 40-45) in the northern periphery of the cemetery, and Sample 5 was taken from Burial 172 (female aged 40-50) in the southern periphery. According to Denisova et al. (1985), Burial 47 belongs to the older part of the cemetery, while burials 120 and 172, at the periphery, belong to the younger part of the cemetery. Burial 79a,b is located in an area between the older and the younger parts of the cemetery (Denisova et al. 1985: 143-7). In the following model dating analyses, we have assumed that both remains in Burial 79a,b are contemporary and thus we have always combined the individual dates.

The ${ }^{14} \mathrm{C}$ samples of bone collagen were treated with a modified Longin method (Longin 1971). The bone sample was first mechanically and ultrasonically cleaned in distilled water. It was then dried at $100{ }^{\circ} \mathrm{C}$ overnight, ground to 0.5 - to 1 -mm grains on which hydrolysis and removal of carbonate contaminants were performed with $10 \% \mathrm{HCl}$ at $5{ }^{\circ} \mathrm{C}$. After neutralization, humic acids were removed from the sample by leaching the insoluble residue at room temperature with $0.5 \% \mathrm{NaOH}$ for 18 $20 \mathrm{hr}$. The solution was again neutralized and the sample placed in distilled water with $\mathrm{pH}$ adjusted to $2-3$ by adding $\mathrm{HCl}$. This was left at $90^{\circ} \mathrm{C}$ for $24 \mathrm{hr}$ with continuous mixing. This process formed soluble gelatin from which insoluble humic acids were separated by a centrifuge. The remaining soluble gelatin was then dried for packing and combustion.

Pretreated samples were mixed with a stoichiometric excess of $\mathrm{CuO}$ and packed into glass ampoules, which were pumped into vacuum and torch-sealed. The packed samples were combusted at $520{ }^{\circ} \mathrm{C}$ overnight. The released $\mathrm{CO}_{2}$ was collected and purified with liquid $\mathrm{N}_{2}$ and ethanol traps at -196 and $-85^{\circ} \mathrm{C}$, respectively. After purifying and measuring the sample $\delta^{13} \mathrm{C}$ value with IRMS (Finnigan MAT Delta-E) for fractionation correction, the $\mathrm{CO}_{2}$ samples were converted to graphite targets in the presence of zinc powder and iron catalyst (Slota et al. 1986). Accelerator mass spectrometry (AMS) measurements were performed at the Uppsala Tandem Laboratory.

Fractions of the pretreated samples were weighed (typically $0.5 \mathrm{mg}$ ), packed into tin cups (Elemental Microanalysis D4019), and analyzed with an EA-IRMS (NC 2500 + Thermo Finnigan Delta Plus Advantage) for $\delta^{13} \mathrm{C}$ and $\delta^{15} \mathrm{~N}$ values. Based on multiple reference measurements (IAEA-C3, N1, $\mathrm{N} 2$, and laboratory references chitin, caffeine) and international intercomparison measurements on multiple isotopes (Boettger et al. 2007), the analytical errors were estimated to be less than $0.2 \%$ for carbon and $0.3 \%$ for nitrogen. Quality of the collagen extraction procedure and resulting collagen for human samples were controlled by measuring the $\mathrm{C} / \mathrm{N}$ ratios.

Chronological analyses were conducted using the OxCal v 4.1 software (Bronk Ramsey 2009a) and IntCal09 calibration curve (Reimer et al. 2009). An example of the model treating phases of ceme- 


\section{Oinonen et al.}

tery and hillfort independently is given in Figure 3. All the analyzed results and phase boundaries ("Boundary" option in OxCal) have been given by using 95\% highest posterior density (HPD) ranges. We utilize the concepts of agreement index (Bronk Ramsey 1995, 2009a) and outlier analysis (Bronk Ramsey 2009b) to estimate the quality of the chronological models. For outliers, we have adopted the General model with the basic settings recommended in Bronk Ramsey (2009b). Since we aim to obtain quantitative information on the beginning and the end of cemetery and hillfort usages, we have established chronological models for the site by assuming both the prior information of cemetery predating the hillfort and these being totally independent of each other. As a sensitivity analysis and to estimate the maximal role of a potential marine reservoir effect, the reservoir correction model was also experimented for all the data sets. Since the data set is fairly limited, we consider particularly whether the summed calendar year probability distributions are a more reasonable way to estimate the occupation period of the site compared to the quantitative phase boundaries. Finally, we compared the obtained results with the archaeological consensus obtained by the typological and the stratigraphical data.

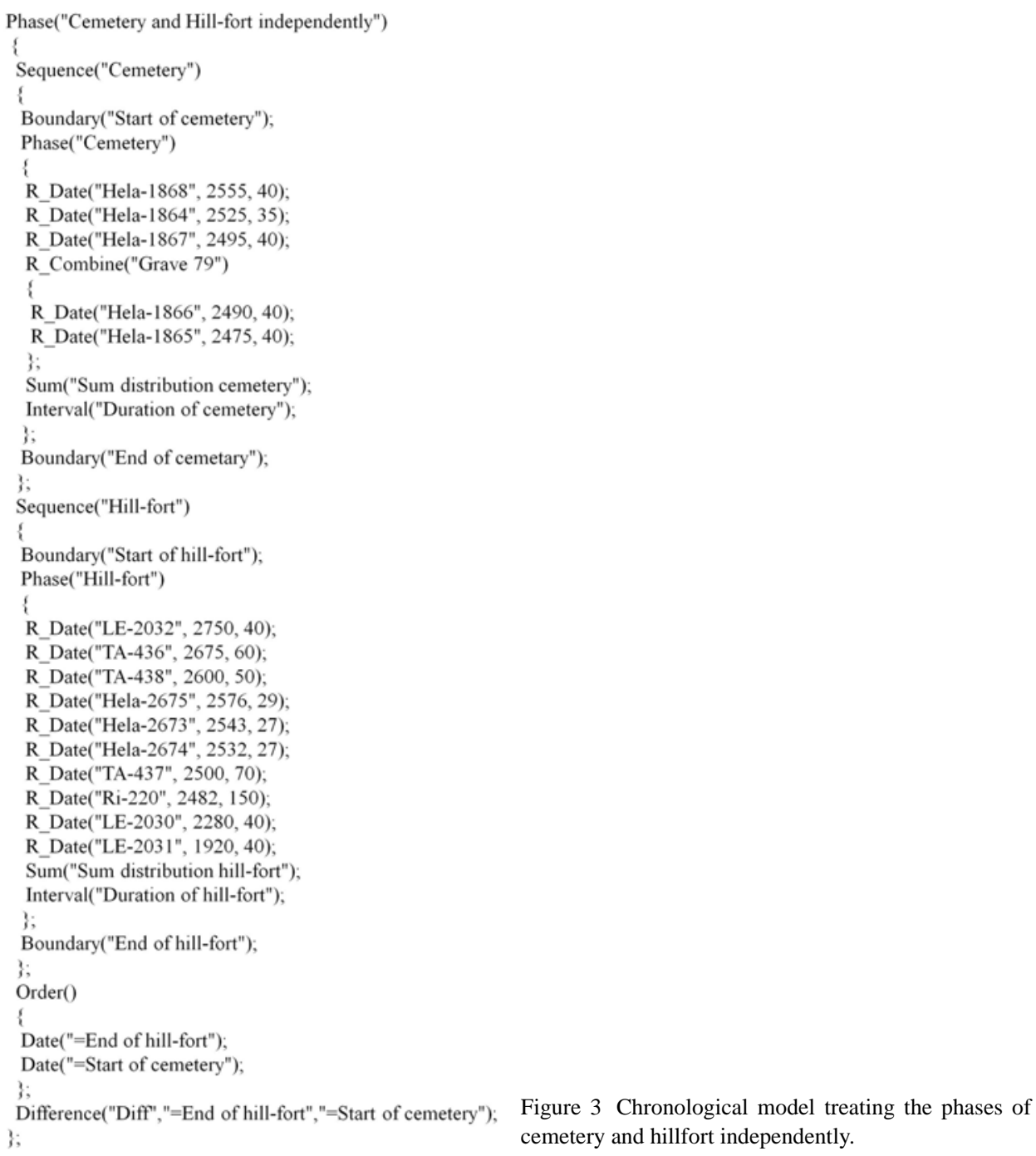


Stones, Bones, and Hillfort: ${ }^{14} \mathrm{C}$ Dating of Ķivutkalns

\section{RESULTS AND DISCUSSION}

\section{Raw Data}

The results of all the individual ${ }^{14} \mathrm{C}$ dates made on Ķivutkalns are shown in Table 1 together with isotopic ratios, if available. Whereas the old ${ }^{14} \mathrm{C}$ dates on the hillfort spread to a somewhat wide range, the new dates are concentrated within a very narrow range around $2500 \mathrm{BP}$. Particularly, there is 1 date (LE-2031) differing clearly from the others for the hillfort. The OxCal code initially assumes the a priori outlier probability to be 5\% (Bronk Ramsey 2009b). Our chronological models assuming phase independence interpret the individual date of LE-2031 to be an outlier with varying probabilities of $0-40 \%$ but having the individual agreement index always larger than $60 \%$.

Table 1 The Ķivutkalns sample details. The measurements performed within this work are coded as Hela-xxxx. Other dates are according to Graudonis (1989).

\begin{tabular}{|c|c|c|c|c|c|c|c|c|}
\hline Context & Lab code & Material & Details & Location, depth & Age (BP) & $\begin{array}{l}\delta^{13} \mathrm{C} \\
\% \text { \% }\end{array}$ & $\begin{array}{l}\delta^{15} \mathrm{~N} \\
\% \text { \% }\end{array}$ & $\begin{array}{l}\mathrm{C} / \mathrm{N} \\
\text { ratio }\end{array}$ \\
\hline Cemetery & Hela-1864 & Human bone & Male 35-40 yr & Burial 47 & $2525 \pm 35$ & -20.7 & 10.0 & 3.5 \\
\hline Cemetery & Hela-1865 & Human bone & Child 2 yr & Burial 79a & $2475 \pm 40$ & -18.4 & 11.6 & 3.3 \\
\hline Cemetery & Hela-1866 & Human bone & Male 35-45 yr & Burial 79b & $2490 \pm 40$ & -19.4 & 10.5 & 3.3 \\
\hline Cemetery & Hela-1867 & Human bone & Male 40-45 yr & Burial 120 & $2495 \pm 40$ & -20.2 & 10.1 & 3.3 \\
\hline Cemetery & Hela-1868 & Human bone & Female $40-50$ yr & Burial 172 & $2555 \pm 40$ & -19.4 & 9.8 & 3.3 \\
\hline Hillfort & LE-2032 & Charcoal & & Area VII, $1 \mathrm{~m}$ & $2750 \pm 40$ & & & \\
\hline Hillfort & TA-436 & Charcoal & & Area XII, 1 m & $2675 \pm 60$ & & & \\
\hline Hillfort & TA-438 & Charcoal & & Area I, 0.8-1.0 m & $2600 \pm 50$ & & & \\
\hline Hillfort & TA-437 & Charcoal & & Area I, 1.0-1.1 m & $2500 \pm 70$ & & & \\
\hline Hillfort & Ri-220 & Charcoal & & Area V, 0.85-1.10 m & $2482 \pm 150$ & & & \\
\hline Hillfort & LE-2030 & Charcoal & & Area VIII, 1 m & $2280 \pm 40$ & & & \\
\hline Hillfort & LE-2031 & Charcoal & & Area VII, 1 m & $1920 \pm 40$ & & & \\
\hline Hillfort & Hela-2673 & Animal bone & Bone splinter & Area $10,0.75 \mathrm{~m}$ & $2543 \pm 27$ & -22.0 & 7.1 & \\
\hline Hillfort & Hela-2674 & Animal bone & Bone awl & Area 12, $1.53 \mathrm{~m}$ & $2532 \pm 27$ & -21.5 & 6.9 & \\
\hline Hillfort & Hela-2675 & Animal bone & Bone awl & Area $10,1.90 \mathrm{~m}$ & $2576 \pm 29$ & -21.4 & 6.8 & \\
\hline
\end{tabular}

On the other hand, we do not have further knowledge on the quality of the dating procedure for LE2031. The sample itself was obtained earlier from the timbers of the wooden chambers within the rampart. Therefore, it integrally belongs to the site. Altogether, it is difficult to definitely consider the individual date of LE-2031 to be an outlier. We maintain the possibility that the dating is valid and therefore do not use the outlier analysis option mechanically within our analyses, since it may reduce too much the weight of the otherwise acceptable date of LE-2031. In addition, based on the agreement indices, we do not have reasons to exclude any other dates from the chronological models either; we thus use the whole data set of Table 1 to establish the ${ }^{14} \mathrm{C}$ chronology for Kivutkalns.

\section{Diet}

We compare the obtained stable isotopic data to the data sets of human bone collagen of Svemb, Sweden (Eriksson and Liden 2013); Resmo III phase, Öland (Eriksson et al. 2008); Västerbjers, Gotland (Eriksson 2004); and Zvejnieki, Latvia (Eriksson 2006) in Figure 4. The Västerbjers site economy has been clearly based on marine resources, whereas the terrestrial influence was considered being strongest in the Swedish mainland in Svemb and within Bronze Age contexts in Resmo (Eriksson and Liden 2013). Zvejnieki in Latvia stands out as a context with exceptionally pronounced use of freshwater resources (Eriksson 2006). The Kivutkalns human bone collagen isotopic ratios resemble the ones measured for Svemb and Resmo and indicate strongly terrestrial dietary origin. Based on isotopic values and using the Svemb data as a reference, marine fractions on the 


\section{Oinonen et al.}

order of $25 \%$ could possibly be envisioned for Ķivutkalns individuals. The contemporary animal remains from Kivutkalns site fall into the group of typical terrestrial herbivores (Schoeninger and DeNiro 1984), thus indicating the use of terrestrial resources.

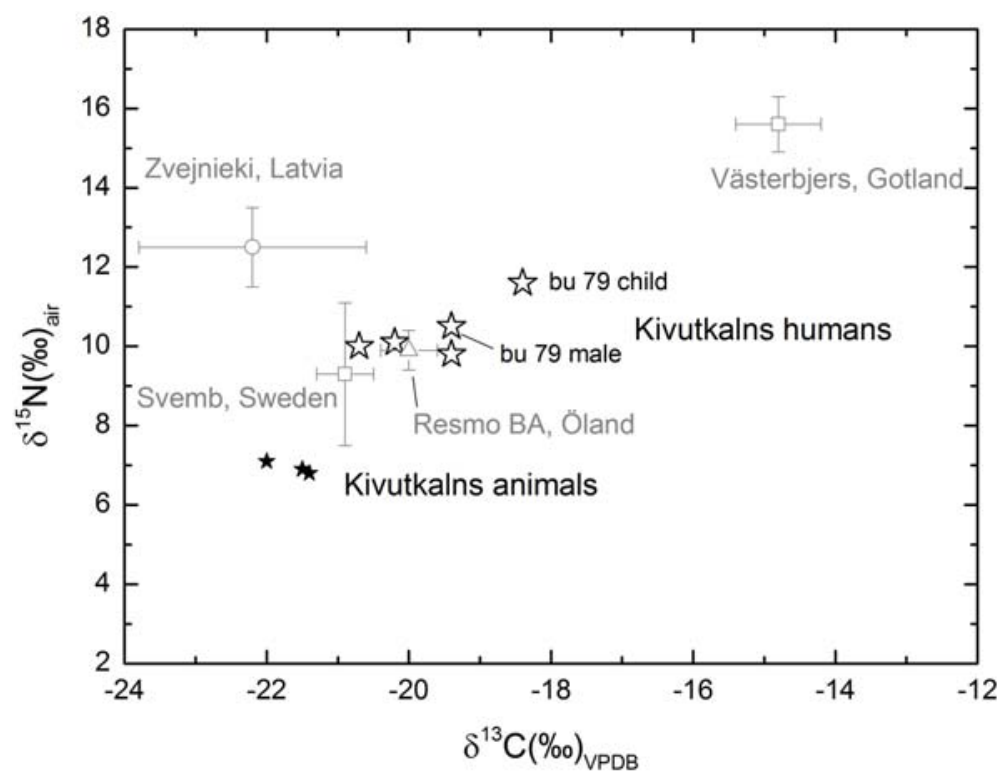

Figure 4 Carbon and nitrogen stable isotopic ratios of Ķivutkalns bone samples (black) compared to Svemb, Resmo (Bronze Age), Västerbjers and Zvejnieki reference data sets (gray) of humans by Eriksson and Liden (2013 and references therein). The uncertainties of the measured isotopic values are smaller than the symbol sizes.

The elevated $\delta^{13} \mathrm{C}$ and $\delta^{15} \mathrm{~N}$ values for the infant are possibly due to breastfeeding. Typically, breastfeeding of an infant causes an elevation of 1 and 2-3 in the levels of carbon and nitrogen isotopic ratios, respectively, compared to the maternal values (Fuller et al. 2006). The remains of the infant were lying in Burial 79a,b together with male individual remains. The ${ }^{14} \mathrm{C}$ date of the male is $15{ }^{14} \mathrm{C}$ yr older than the date of the infant (Table 1 ) and thus the dates are practically equal. Furthermore, regeneration of bone induces an own age of the order of a decade for the bones of the adults, thus even reducing the time difference. If taking into account the assumed breastfeeding-caused elevation, the estimated maternal isotopic values of the infant are close to the values measured for the male individual in the same grave. Based on the archaeological (same grave), ${ }^{14} \mathrm{C}$ (contemporary date), and stable isotopic (similar diet) evidence, it is reasonable to think that the 2 deceased belong to the same family and may even be a father and his child.

\section{Sensitivity Analyses}

Based on carbon and nitrogen stable isotopic values, we performed a sensitivity study to estimate how the possible reservoir age corrections affect the eventual conclusions of the study. In addition to the reservoir age corrections for human bones, in the sensitivity analysis we have assumed a certain own age for wood/charcoal ( $40-80{ }^{14} \mathrm{C}$ yr, Oinonen et al. 2010). This is based on an average difference of ${ }^{14} \mathrm{C}$ ages of charcoal and shorter-lived samples within Finnish Neolithic contexts.

The global average of the marine reservoir effect is close to $400 \mathrm{yr}$ (Reimer et al. 2009). The Baltic Sea, being characterized by mixing of freshwater and saltwater sources and the marine contribution, 
is expected to be lower. The maximal Baltic Sea reservoir effect has been adopted as an average of the 8 measured values (http://calib.qub.ac.uk/marine/) available: $279 \pm 77$ yr (as in Pesonen et al. 2012). To account for the suspected spatiotemporal variation, we introduce a slightly larger uncertainty: $\mathrm{R}_{\text {Baltic }}=279 \pm 100$ yr. The correction is following the method described in Pesonen et al. (2012) but using separately both carbon and nitrogen values for the correction. To estimate the marine fraction (MF), we adopted the averages of the stable isotopic data from Neolithic contexts of Västerbjers $\left(\delta^{13} \mathrm{C}_{\text {ave }}=-14.8 \pm 1.0 \%\right.$; $\delta^{15} \mathrm{~N}_{\mathrm{ave}}=15.6 \pm 1.0 \%$; Eriksson 2004) and Svemb $\left(\delta^{13} \mathrm{C}_{\mathrm{ave}}=\right.$ $-20.9 \pm 1.0 \%$; $\delta^{15} \mathrm{~N}_{\text {ave }}=9.3 \pm 2.0 \%$; Eriksson and Lidén 2013) to correspond to full marine $(\mathrm{R}=$ $\left.\mathrm{R}_{\mathrm{Baltic}}\right)$ and terrestrial $(\mathrm{R}=0)$ diets, respectively. We then performed linear interpolations between these extremes to obtain relations for marine fractions as a function of $\delta^{13} \mathrm{C}_{\text {bone }}$ and $\delta^{15} \mathrm{~N}_{\text {bone. }}$. Eventually, we scaled down the maximal reservoir effect correction with the estimated $\mathrm{MF}_{\mathrm{C}, \mathrm{N}}$ to obtain the reservoir effect corrections $\left(\mathrm{R}_{\mathrm{C}, \mathrm{N}}\right)$ as

$$
\begin{aligned}
& R_{C}=M F_{C} \times R_{\text {Baltic }}=\left[A_{C}+B_{C} \times \delta^{13} C_{\text {bone }}\right] \times R_{\text {Baltic }} \\
& R_{N}=M F_{N} \times R_{\text {Baltic }}=\left[A_{N}+B_{N} \times \delta^{15} N_{\text {bone }}\right] \times R_{\text {Baltic }}
\end{aligned}
$$

In the above relations, the parameters of the linear interpolations are given by $\mathrm{A}_{\mathrm{C}, \mathrm{N}}$ and $\mathrm{B}_{\mathrm{C}, \mathrm{N}}$. Based on sampling the interpolations within the assumed node uncertainties and $\Delta \mathrm{R}_{\text {Baltic }}$, we estimate the maximal uncertainty of the reservoir age correction to be $40-60{ }^{14} \mathrm{C}$ yr. We adopted the larger of Equation 1a,b as the final reservoir effect correction for each ${ }^{14} \mathrm{C}$ date. The obtained reservoir effect corrections were finally subtracted from the ${ }^{14} \mathrm{C}$ ages to deduce corrected ages for which the calibrations for sensitivity analyses were then performed. It should be noted that the animal bone isotopic values were considered fully terrestrial and, therefore, no reservoir age corrections were made.

The estimated marine fractions of $0.1-0.25$ yield maximally to $\sim 30-70{ }^{14} \mathrm{C}$ yr reservoir age corrections for the human bone collagen ages. The assumed wood own-age corrections are of the same order; thus, both the cemetery and the hillfort chronologies would be shifted about a half a century later if the corrections are performed. The magnitude of the corrections is also nearly equal to an uncertainty of an individual ${ }^{14} \mathrm{C}$ date and negligible compared to the difference between our cemetery dates and the archaeological consensus. Ultimately, we conclude that the corrections do not significantly affect the main conclusions of the paper.

\section{Chronology}

Figure 5 shows an example of the obtained information on the hillfort chronology by using the model of Figure 3. Phase boundaries for the start and the end of the hillfort occupation are obtained in both sides of the sum distribution of the calendar year probabilities. Particularly, the end boundary is wide due to the LE-2031 date representing the later stage of the occupation. Therefore, it seems that the range of the sum distribution may provide a more realistic picture on the occupation period. Below, we discuss the chronologies mainly based on the ranges of the sum distributions, but display also the phase boundaries.

When treating the phases of cemetery and hillfort completely independently, the agreement indices $\left(\mathrm{A}_{\text {model }}\right)$ of the chronological models are always larger than the threshold value of $60 \%$. The highest value $\left(\mathrm{A}_{\text {model }}=101\right)$ is obtained when the raw data are used without any corrections or outlier options (Figure 3). On the other hand, assuming a sequence of the cemetery predating the hillfort provides agreement indices always smaller than $60 \%$ the highest being around $20 \%$. This indicates that — concerning the present set of data and the Bayesian model—a prior assumption of the cemetery predating the hillfort is not justified. We therefore are guided to assume totally independent 


\section{Oinonen et al.}

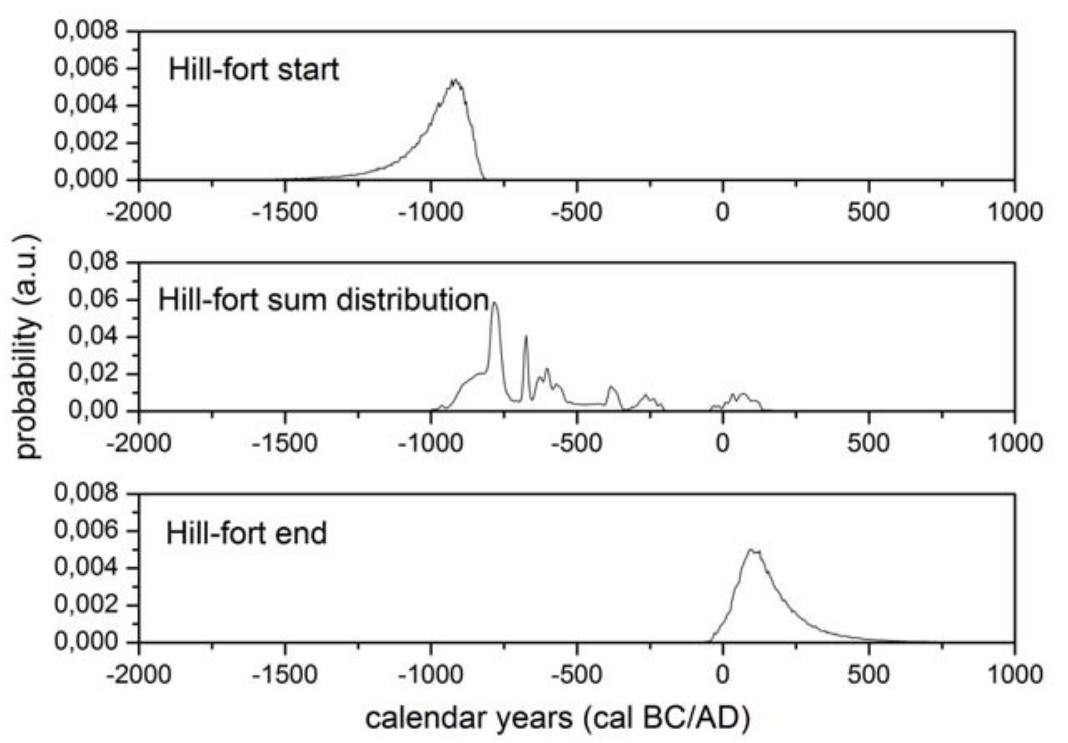

Figure 5 An example of the analysis results utilizing the phase boundaries and sum distributions within OxCal for all the hillfort data $\left(10{ }^{14} \mathrm{C}\right.$ dates). We consider the sum distributions to provide a more meaningful estimate for the occupation period with such a small amount of dates.

phases for the cemetery and the hillfort. By doing so on the uncorrected data set, we obtain the results shown in Figure 6 and listed in Table 2. The sum distribution of the ${ }^{14} \mathrm{C}$ dates cover the period 950 cal BC-cal AD 150. This can be compared to the archaeological consensus: in Figure 6 it has been assumed that the archaeology provides support for the hillfort existence from the mid-7th century BC (650 BC) to the mid-1st century AD (AD 50). The combined old and new data more or less support this archaeological consensus. Particularly, it should be noted that the oldest hillfort dates (LE-2032, TA-438, TA-436) are from charcoal samples possibly prone to own age. This could explain the sum distribution to spread beyond the mid-7th century BC. Furthermore, the 3 iron knives may as well be from the 1st century AD, which then would coincide with the outlying LE2031 date. The emerging understanding of the hillfort usage fits well into the overall picture within the Baltic Sea. As discussed above (Stenberger 1979; Lang 2007b), building of the hillforts began and evolved quickly during the same period of time within the Baltic region and in Scandinavia.

The 5 new human bone collagen dates on the cemetery are concentrated in a very narrow period of time, $800-510 \mathrm{cal} \mathrm{BC}$, according to the sum distribution. This is much later compared to the assumption of the cemetery predating the hillfort and seems to temporally overlap with the period of the hillfort. The model analysis provides even $100 \%$ probability that the start of the hillfort is earlier than the end of the cemetery. Thus, there is a clear inconsistency between the archaeological interpretation based on stratigraphy and the present ${ }^{14} \mathrm{C}$ results. This is not altered by the possible marine corrections since the reservoir age corrections would push the human bone collagen dates in a younger direction, not older. Since the bone collagen dates are tightly concentrated, outlier analysis does not change the situation either. It would be very difficult to explain the results by technical difficulties, since these were not observed during the sample preparation. In addition, we consider the results of Burial 79a,b to provide support for the high-quality measurements: both the ${ }^{14} \mathrm{C}$ dates and the isotopic ratios correspond well to the assumption of contemporary nuclear family remains. 
Stones, Bones, and Hillfort: ${ }^{14} \mathrm{C}$ Dating of Ķivutkalns

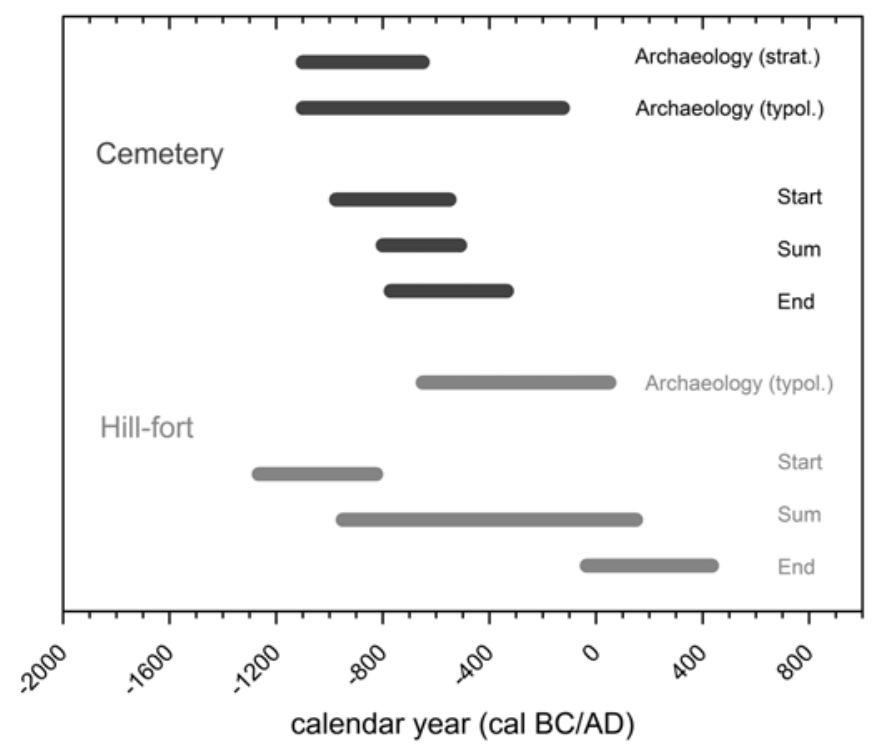

Figure 6 Comparison of the results of archaeology and the present set of ${ }^{14} \mathrm{C}$ dates for the cemetery (black) and hillfort (gray) by using 95.4\% HPD intervals.

Table 2 The results of the eventual Kivutkalns dating model without reservoir and own-age corrections and outlier detection (Figure 3 ). The agreement index was $A_{\text {model }}=101 \%$. *Based on typology. ${ }^{* *}$ Based on stratigraphy.

\begin{tabular}{llc}
\hline Context & Distribution & $95.4 \%$ HPD \\
\hline Cemetery & & $\sim 1100-125$ BC* \\
Cemetery & & $1100^{*}-650$ BC** \\
Cemetery & Phase Start & $975-550$ cal BC \\
Cemetery & Sum & $800-510 \mathrm{cal} \mathrm{BC}$ \\
Cemetery & Phase End & $770-335 \mathrm{cal} \mathrm{BC}$ \\
Hillfort & & 650 BC-50 AD* \\
Hillfort & Phase Start & $1265-825 \mathrm{cal} \mathrm{BC}$ \\
Hillfort & Sum & $950 \mathrm{cal}$ BC-150 cal AD \\
Hillfort & Phase End & $35 \mathrm{cal} \mathrm{BC}-435 \mathrm{cal} \mathrm{AD}$ \\
\hline
\end{tabular}

The well-known ${ }^{14} \mathrm{C}$ plateau at $800-400 \mathrm{cal} \mathrm{BC}$ in the ${ }^{14} \mathrm{C}$ calibration curve (Reimer et al. 2009) spreads the calendar year probability distributions to a wide time window. Our new dates fall within this plateau. Affected also by the modest statistical uncertainty of the older dates, the sum distributions of the cemetery and hillfort overlap strongly. This leaves space for some speculations. Some of the charcoal dates for the hillfort (LE-2032, TA-438, TA-436) are earlier than the dates for burials in the cemetery. This could possibly be explained by the old-tree effect, i.e. that timber from very old trees (hundreds of years old) was used in the structures of the hillfort. In this case, the ${ }^{14} \mathrm{C}$ date may be giving not the date when the trees were cut, but a much earlier date. It is possible that the moderate own-age correction tested would not take such anomaly into account. We have addressed the effect of removal of 3 charcoal dates (LE-2032, TA-438, -436) from the data set and ran a model that assumes the cemetery predating the hillfort. The agreement index of such a model is close to the acceptable level i.e. $A_{\text {model }}=54.6 \%$. Such a model would restrict the cemetery use to 800-600 cal BC, hillfort use to $760 \mathrm{cal}$ BC-cal AD 150, and the boundary between the two to 775-610 cal BC. 


\section{Oinonen et al.}

On the other hand, the establishment of the hillfort earlier than 775-610 cal BC is supported also by the typological evidence.

Regarding the form of burial (inhumation or cremation), it is fairly clear that cremation was a later practice. This is indicated by the following (Denisova et al. 1985:45-6): 1) some of the cremations are still reminiscent of inhumation practices, namely that the cremated remains were placed in an elongated wooden coffin, striving to arrange the bones in anatomical order (cremated skeleton graves); 2) later, this practice is discontinued and the cremated remains are placed in round bark containers; 3 ) one of the graves containing the cremation (P) had been dug above the inhumation (\#198) without damaging it; 4) the cremations placed in elongated wooden coffins had in no case disturbed other, earlier burials. This indicates that grave markers must still have been preserved. On the other hand, some of the graves with cremated remains placed in a round bark container disturbed the earlier burials. It can be assumed that by this time some of the grave markers were no longer preserved to prevent this happening. So far, no cremations have been ${ }^{14} \mathrm{C}$ dated, so it is impossible to confirm the sequence of burial traditions at present. However, we recognize the possibility to shed more light into the ordering of the cemetery and hillfort by performing cremated bone datings.

The Ķivutkalns bronze-working center was located within one of the most important routes of trade and influences in the Baltic area, i.e. the Western Dvina River (Daugava River). Based on the iron artifacts found, the bronze-working tradition was probably continued as iron metallurgy whenever the technology was adopted. The active period of development was characterized by emergence of hillforts and the turn of bronze working to iron metallurgy all over northern Europe- the Baltic Sea being the extension of the ancient highways of water routes. The metal implements of the southern Scandinavian type and from the regions in the Middle Volga reached even Finland (Lavento 2001). Whether the building of contemporary hillforts was needed also at the northern shores of the Baltic Sea is still somewhat an open question but not excluded (Luoto 1984:166-8). The study of Ķivutkalns may act as a trigger for a larger collaborative study within a broader geographical context.

\section{CONCLUSIONS}

The archaeological knowledge based on stratigraphy supports the idea of the Kivutkalns hillfort having been built on top of the older cemetery. The present data set of human and animal bone collagen for Ķivutkalns cemetery and hillfort question this assumption. Combining the new animal bone data with existing ${ }^{14} \mathrm{C}$ dates of charcoal provides supporting evidence for archaeological consensus date of the hillfort usage during the 1 st millennium BC. Five human bone collagen ${ }^{14} \mathrm{C}$ dates are surprisingly young and suggest overlapping periods for usage of the cemetery and the hillfort. This contradiction to the archaeological knowledge can be explained neither by a possible reservoir age correction nor by analysis options. However, the still limited amount of data, overlapping periods, and possibility of an old-wood effect leaves the contradiction still unanswered. The Ķivutkalns context allows for broader collaborative effort including cremated bone dating, utilization of stratigraphical information as a model priori, and even links to ancient DNA studies of the largest Bronze Age context in Latvia. We hope to pursue more investigations in the future and are confident to solve the challenges even in larger geographical setting.

\section{REFERENCES}

Boettger T, Haupt M, Knller K, Weise SM, Waterhouse JS, Rinne KT, Loader NJ, Sonninen E, Jungner H, Masson-Delmotte V, Stievenard M, Guillemin M, Pierre M, Pazdur A, Leuenberger M, Filot M, Saurer M, Reynolds CE, Helle G, Schleser GH. 2007. Wood cellulose preparation methods and mass spectrometric analyses of $\delta^{13} \mathrm{C}, \delta^{18} \mathrm{O}$, and nonexchangeable $\delta^{2} \mathrm{H}$ values in cellulose, sugar, and starch: an interlaboratory comparison. Analytical Chemistry 79(12):4603-12.

Bronk Ramsey C. 1995. Radiocarbon calibration and 


\section{Stones, Bones, and Hillfort: ${ }^{14} \mathrm{C}$ Dating of Kivutkalns}

analysis of stratigraphy: the OxCal program. Radiocarbon 37(2):425-30.

Bronk Ramsey C. 2009a. Bayesian analysis of radiocarbon dates. Radiocarbon 51(1):337-60.

Bronk Ramsey C. 2009b. Dealing with outliers and offsets in radiocarbon dating. Radiocarbon 51(3):102345.

Denisova R, Graudonis J, Gravere R. 1985. Kivutkalnskij mogilnjik epoki bronzi [The Bronze Age Cemetery Ķivutkalns]. Riga: Zinātne.

Eriksson G. 2004. Part-time farmers or hard-core sealers? Västerbjers studied by means of stable isotope analysis. Journal of Antropological Archaeology 23(2): 135-62.

Eriksson G. 2006. Stable isotope analysis of human and faunal remains from Zvejnieki. In: Larsson L, Zagorska I, editors. Back to the Origin: New Research in the Mesolithic-Neolithic Zvejnieki Cemetery and Environment, Northern Latvia. Lund: Almqvist and Wiksell International. p 183-215.

Eriksson G, Lidén K. 2013. Dietary life histories in Stone Age Northern Europe. Journal of Anthropological Archaeology 32(3):288-302.

Eriksson G, Linderholm A, Fornander E, Kanstrup M, Schoultz P, Olofsson H, Lidén K. 2008. Same island, different diet: cultural evolution of food practice on Öland, Sweden, from the Mesolithic to the Roman Period. Journal of Anthropological Archaeology 27(4): 520-43.

Fuller BT, Fuller JL, Harris DA, Hedges REM. 2006. Detection of breastfeeding and weaning in modern human infants with carbon and nitrogen stable isotope ratios. American Journal of Physical Anthropology 129(2):279-93.

Graudonis J. 1989. Nocietinātās apmetnes Daugavas lejtecē [The Fortified Settlements in the Lower Daugava]. Riga: Zinātne.

Grigalavičiene E, Merkevičius A. 1980. Drevneishije metallicheskije izdelija $v$ Litve (II-I tysiacheletia do n.e.) [Ancient Bronzeware in Lithuania (II-I millennia B. C.]. Vilnius: Mokslas.

Lang L. 2007a. The Bronze and Early Iron Ages in Estonia. Estonian Archaeology 3. Tartu: Tartu University Press.

Lang L. 2007b. Baltimaade pronksi- ja rauaaeg. Tartu: Tartu likooli kirjastus.

Lavento M. 2001. Textile ceramics in Finland and on the Karelian Isthmus. Nine Variations and Fugue on a Theme of C. F. Meinander. Finska Fornminnesfreningens Tidskrift 109. Sastamala: Vammalan Kirjapaino Oy.
Longin R. 1971. New method of collagen extraction for radiocarbon dating. Nature 230(5291):241-2.

Luoto J. 1984. Liedon Vanhanlinnan mkilinna. Finska Fornminnesfreningens Tidskrift 87. Sastamala: Vammalan Kirjapaino Oy.

Oinonen M, Pesonen P, Tallavaara M. 2010. Archaeological radiocarbon dates for studying the population history in eastern Fennoscandia. Radiocarbon 52(2): 393-407.

Pesonen P, Oinonen M, Carpelan C, Onkamo P. 2012. Early Subneolithic ceramic sequences in eastern Fennoscandia-a Bayesian approach. Radiocarbon 54(34):661-76.

Reimer PJ, Baillie MGL, Bard E, Bayliss A, Beck JW, Blackwell PG, Bronk Ramsey C, Buck CE, Burr GS, Edwards RL, Friedrich M, Grootes PM, Guilderson TP, Hajdas I, Heaton T, Hogg AG, Hughen KA, Kaiser KF, Kromer B, McCormac FG, Manning SW, Reimer RW, Richards DA, Southon JR, Talamo S, Turney CSM, van der Plicht J, Weyhenmeyer CE. 2009. IntCal09 and Marine09 radiocarbon age calibration curves, 0-50,000 years cal BP. Radiocarbon 51(4): 1111-50.

Schoeninger MJ, DeNiro MJ. 1984. Nitrogen and carbon isotopic composition of bone collagen from marine and terrestrial animals. Geochimica et Cosmochimica Acta 48(4):625-39.

Slota Jr PJ, Jull AJT, Linick TW, Toolin LJ. 1986. Preparation of small samples for ${ }^{14} \mathrm{C}$ accelerator targets by catalytic reduction of CO. Radiocarbon 29(2):303-6.

Stenberger M. 1979. Det forntida Sverige. Tredhe upplagen. Lund: Awe/Gebers.

Vandkilde H, Rahbek U, Rasmussen K. 1996. Radiocarbon dating and the chronology of Bronze Age Southern Scandinavia. Acta Archaeologica 67:183-98.

Vankina L. 1960. Noveishie nahodki epokhi bronzi na territorii Latviiskoi SSR [New finds of the Bronze Age in the territory of Latvia]. Sovetskaia Arheologia 3:153-61.

Vasks A. 1994. Brikuļu nocietinātā apmetne. Lubāna zemiene vēlajā bronzas un dzelzs laikmetā (1000. g. pr. $K r .-1000$. g. pēc Kr.). [Brikul̦i Fortified Settlement. The Lubāna Lowlands in the Late Bronze and Iron Age (1000 BC - 1000 AD)]. Riga: Preses Nams Publishers.

Vasks A. 2003. Akmeņu krāvuma kapulauki Kurzemē. [Tarand (Stone setting) cemeteries in Kurzeme]. Arheoloǵija un etnogrāfia 21:141-53.

Vasks A. 2010. Latvia as part of a sphere of contacts in the Bronze Age. Archaeologia Baltica 13:153-60. 